\title{
Prosfek Penumbuhan Wirausahawan Muda Pertanian (PWMP) Di Pulau Lombok
}

\author{
Tajidan*, Efendy, Halil, Edy Fernandez \\ Program Sudi Agribisnis, Jurusan Sosial Ekonomi Pertanian \\ Universitas Mataram, INDONESIA;
}

Article history

Received: 30April 2019

Revised:13Juni 2019

Accepted: 14Juni 2019

*Corresponding

Author:Tajidan

Program Sudi Agribisnis,

Jurusan Sosial Ekonomi

Pertanian

Universitas Mataram,

Indonesia

Email*:tajidan@unram.ac.id
Abstract:The objectives of the community service are: maintaining the alumni commitment as agricultural young entrepreneurs; increase the capacity and ability of alumni in the management of business in agriculture; increasing the business scale by adding the ability to finance agribusiness businesses; and developing business networks (net-working) and financing and marketing cooperation. The output expected as an output of this service activity is an article published in national or international journals. To achieve the purpose of this service, it is carried out with a coaching and mentoring approach. Coaching is done by the focus group discussion (FGD) method, training with the agribusiness field school method, and mentoring in the problem solving method. From a series of implementation activities can be summarized as follows: the commitment of alumni as young agricultural entrepreneurs is still able to be held which is shown by the still strong spirit and entrepreneurial spirit; (the alumni who are members of the PWMP Group have the ability to increase the capacity of business management in agriculture, including 3 (three) of the 7 (seven) PWMP groups that have opened business branches and appointed employees to assist production activities and services to customers; in general there has been an increase in the ability of financing sourced from an average allowance for operating results of $18.3 \%$ from November 2017 to July 2018 or $2.29 \%$ / month; and the development of business networks and marketing is still an obstacle for most young agricultural entrepreneurs, except the PWMP Bintang Tani Group which has a business network and regular customers in the marketing aspect.

Keywords: business branch; business network; capability; commitment; customer

Abtrak:Tujuan dilaksanakannya pengabdian pada masyarakat ini adalah: mempertahankan komitmen alumni sebagai wirausahawan muda pertanian; meningkatan kapasitas dan kemampuan alumni dalam pengelolaan bisnis bidang pertanian; meningkatkan skala usaha melalui penambahan kemampuan pembiayan usaha bidang agribisnis; dan mengembangan jaringan bisnis (net-working) dan kerjasama pembiayaaan dan pemasaran. Output yang diharapkan sebagai keluaran kegiatan pengabdiandian ini adalah artikel yang diterbitkan di jurnal nasional atau internasional. Pencapaian tujuan pengabdian ini dilaksanakan dengan pendekatan pembinaan dan pendampingan. Pembinaan dilasanakan dengan metode focus group discussion (FGD), pelatihan dengan metode sekolah lapang agribisnis, dan pendampingan dilasanaan dengan metode problem solving. Hasil pelaksanaan kegiatan menunjukkan bahwa: komitmen alumni sebagai wirausahawan muda pertanian masih mampu dipertahanan yang ditunjukkan oleh masih kuatnya jiwa dan semangat kewirausahaannya; para alumni yang tergabung dalam Kelompok PWMP memiliki kemampuan dalam meningkatkan kapasitas pengelolaan usaha bidang pertanian diantaranya 3 (tiga) dari 7 (tujuh) Kelompok PWMP telah membuka cabang usaha dan mengangkat karyawan dalam membantu kegiatan produksi dan pelayanan kepada pelanggan; secara umum telah terjadi peningkatan 
kemampuan pembiayaan yang bersumber dari penyisihan hasil usaha rata-rata sebesar 18,3\% sejak bulan November 2017 sampai dengan bulan Juli 2018 atau 2,29\%/bulan. Pengembangan jaringan bisnis dan pemasaran masih menemui kendala bagi sebagian besar wirausahawan muda pertanian, kecuali Kelompok PWMP Bintang Tani yang telah memiliki jaringan bisnis dan pelanggan tetap pada aspek pemasaran.

Kata Kunci: cabang usaha; jaringan bisnis; kemampuan; komitmen; pelanggan

\section{PENDAHULUAN}

Pembangunan pertanian dewasa ini menghadapi berbagai permasalahan yang tidak ringan diantaranya regenerasi petani. Dewasa ini semakin sulit mendapatkan tenaga kerja di sektor pertanian, ditambah semakin menurunnya minat generasi muda untuk bekerja di sektor pertanian. Penyebabnya adalah bekerja di sektor pertanian terkesan kotor, panas-terik, membutuhkan waktu yang lama untuk memperoleh hasilnya, serta penghasilannya tidak kompetitif. Kesan yang demikian disebabkan realitas bahwa yang terlihatnya sehari-hari adalah petani tradisional yang bekerja di sawah atau di ladang, bergelut dengan tanah, lumpur dan kotor, karena menggunakan teknologi sederhana dan konvensional (Agussabti dan Dahlia, 2018; Musyadardan Azhar, 2018)

Sebagian besar lulusan pendidikan pertanian seperti Sekolah Menengah Kejuruan Pembangunan Pertanian (SMKPP) atau pun tamatan Perguruan Tinggi Pertanian lebih cenderung (preference) sebagai pencari kerja (job seeker) daripada sebagai pencipta lapangan kerja (job creator), sebab kesediaan tamatan Perguruan Tinggi Pertanian agar mau bekerja sebagai wirausahawan pertanian tampak rendah, justru yang menekuni usaha bidang pertanian adalah bukan dari alumni Fakultas Pertanian atau Fakultas Peternakan. Hal ini diduga sebagai akibat sistem pendidikan yang masih pada tataran sebatas mengetahui bukan sampai dengan tataran sebagai pelaku usaha bidang pertanian (Pusat Pendidikan Pertanian, 2017).

Pola pikir (main set) sebagai mana tercermin di atas akan berdampak pada menurunnya jumlah pelaku-pelaku usaha bidang pertanian. Dalam jangka panjang, hal tersebut akan mengakibatkan kelangkaan sumberdaya manusia (SDM) yang bekerja di sektor pertanian, sehingga dikhawatirkan akan mengancam keberlanjutan pembangunan pertanian. Antisipasi risiko kelangkaan SDM bidang pertanian tersebut, maka perlu digerakkan melalui suatu terobosan penumbuhan kesadaran para siswa atau pun mahasiswa pendidikan pertanian untuk memulai kegiatan bisnis pertanian, sehingga ketika mereka tamat sudah siap untuk terjun sebagai pelaku-pelaku usaha bisnis pertanian. Kementerian Pertanian dalam hal ini adalah Badan Penyuluhan dan Pengembangan Sumber Daya Manusia Pertanian mengajak Perguruan Tinggi Pertanian sebagai mitra dalam Program Penumbuhan Wirausahawan Muda Pertanian (PWMP) yang sudah dimulai sejak tahun 2016 (Pusat Pendidikan Pertanian, 2017), namun Fakultas Pertanian Universitas Mataram mulai melaksanakan PWMP Tahun 2017.

Program PWMP adalah suatu terobosan untuk membangkitkan minat dan memulai sebagai wirausawan muda pertanian bagi para alumni Fakultas Pertanian dan Fakultas Perternakan. Proses rekrutmen peserta mulai dari sosialisasi, pendaftaran, seleksi, bimbingan teknis, magang, penyusunan rencana bisnis, dan pemberian hibah start-up dengan cara berkelompok masing-masing 3 (tiga) orang per kelompok (Agussabti dan Dahlia, 2018; Musyadar dan Azhar, 2018). Jumlah kelompok PWMP 
yang telah start-up sebanyak 7 (tujuh) kelompok yang tersebar di semua kabupaten/kota yang ada di Pulau Lombok, yaitu 1 (satu) kelompok di Kota Mataram, 1 (satu) kelompok di Kabupaten Lombok Barat, 2 (dua) kelompok di Kabupaten Lombok Tengah, dan 3 (tiga) kelompok di Kabupaten Lombok Timur. Permasalahannya adalah pembinaan dan pendampingan PWMP diserahkan kepada Perguruan Tinggi Mitra (PT-M), sementara monitoring dan evaluasi dilakukan oleh Panitia Pusat dari Kementerian Pertanian. Kelompok PWMP yang telah start-up tersebut tentu tidak begitu saja dibiarkan tumbuh secara alamiah, sebab akan berisiko pada kemungkinan terhentinya aktivitas usaha di tengah pergulatan bisnis, sehingga berpeluang menghambat tercapainya kemandirian (Prasetyo dan Sutoyo, 2018). Secara rational dibutuhkan pembinaan dan pendampingan untuk mengantisipasi kemungkinan buruk yang akan mereka alami, sebab tantangan persaingan bisnis yang mereka hadapi relatif berat dan membutuhkan pendampingan untuk menjalin net-working dengan para pihak yang menguasai sumber pembiayaan dan pasar (Suaryantini dan Waluyati, 2018).

Sehubungan dengan permasalahan sebagai mana diuraikan di atas, maka penting untuk dipublikasikan Prosfek Penumbuhan Wirausahwan Muda Pertanian (PWMP) di Pulau Lombok. Tujuan pelaksanaan pengabdian kepada masyarakat ini adalah: mempertahankan komitmen alumni sebagai wirausahawan muda pertanian; meningkatan kapasitas dan kemampuan alumni dalam pengelolaan bisnis bidang pertanian; meningkatkan skala usaha melalui penambahan kemampuan pembiayan usaha bidang agribisnis; dan mengembangan jaringan bisnis (net-working) dan kerjasama pembiayaaan dan pemasaran.

\section{Pendekatan}

Kegiatan pengabdian dilaksanakan dengan pendekatan pembinaan dan pendampingan kepada 7 (tujuh) kelompok PWMP yang tersebar di 5 (lima) kabupaten/kota se Pulau Lombok.

\section{Metode Pelaksanaan}

Pembinaan dalam pemecahan permasalahan dilakukan dengan metode :

Focus Group Discussion (FGD), yaitu mengundang perwakilan kelompok PWMP untuk berdiskusi dan pemecahan masalah (problim solving) dengan memilih strategi yang paling sesuai dengan kemampuan dan kapasitas masing-masing.

Pelatihan dilakukan untuk mengidentifikasi dan berupaya mengatasi risiko cuaca, serangan hamapenyakit, dan risiko ekonomi. Metode pelatihan yang diterapkan adalah metode Sekolah Lapang, yaitu kegiatan belajar yang diikuti oleh praktik di lokasi tempat usaha kelompok PWMP.

Pendampingan dilakukan dengan cara mendatangi, mengunjungi, dan mendiskusikan alternatif pemecahan masalah yang sedang dihadapi oleh kelompok PWMP yang disesuaikan dengan ketersediaan sumberdaya yang ada di sekitar mereka.

Pendampingan juga dilakukan dengan metode Studi Kunjungan, yaitu memperkenalkan kelompok PWMP dengan mitra net-working pembiayaan dan pemasaran, serta melakukan negosasi ataupun menjalin kesepakatan perjanjian kerjasama yang saling menguntungkan. 
Tahapan Kegiatan

\begin{tabular}{|c|c|c|c|}
\hline No & Rincian Kegiatan & Indikator Pencapaian Tujuan & Tolak Ukur Keberhasilan \\
\hline 1 & Persiapan & & \\
\hline 1.1 & Rapat Persiapan & $\begin{array}{l}\text { Tercapainya kesepakatan } \\
\text { pembagian tugas rencana } \\
\text { pelaksanaan pembinaan dan } \\
\text { pendampingan }\end{array}$ & $\begin{array}{l}\text { Tersusunnya jadwal tentatif } \\
\text { pelaksanaan FGD, pelatihan, dan } \\
\text { kunjungan lapang }\end{array}$ \\
\hline 1.2 & $\begin{array}{l}\text { Penyusunan Meteri } \\
\text { FGD }\end{array}$ & $\begin{array}{l}\text { Tersusunnya materi FGD oleh } \\
\text { tiap-tiap pelaksana }\end{array}$ & $\begin{array}{l}\text { Dihasilkannya soft file dan print- } \\
\text { out materi FGD }\end{array}$ \\
\hline 1.3 & $\begin{array}{l}\text { Penyusunan strategi } \\
\text { penumbuhan usaha }\end{array}$ & $\begin{array}{l}\text { Tersedianya alternatif strategi } \\
\text { yang paling mungkin diterapkan } \\
\text { oleh peserta PWMP sesuai dengan } \\
\text { ketersediaan sumber daya }\end{array}$ & $\begin{array}{l}\text { Terpilihnya strategi yang sesuai } \\
\text { dengan kondisi masing-masing } \\
\text { kelompok PWMP }\end{array}$ \\
\hline 1.4 & $\begin{array}{l}\text { Penyusunan materi } \\
\text { Pelatihan Sekolah } \\
\text { Lapang }\end{array}$ & $\begin{array}{l}\text { Tersusunnya rumusan indikator } \\
\text { kesehatan usaha }\end{array}$ & $\begin{array}{l}\text { Dihasilnya template laporan } \\
\text { kesehatan usaha }\end{array}$ \\
\hline 1.5 & $\begin{array}{l}\text { Penysunan materi } \\
\text { pengelolaan risiko } \\
\text { bisnis }\end{array}$ & $\begin{array}{l}\text { Terpilihnya ateratif pengendaliana } \\
\text { risiko berdasarkan rialitas risiko } \\
\text { yang dihadapi oleh masing- } \\
\text { masing kelompok PWMP }\end{array}$ & $\begin{array}{l}\text { Tercapainya kesepakatan tentang } \\
\text { upaya-upaya pengendalian risiko }\end{array}$ \\
\hline 2 & Pelaksanaan & & \\
\hline 2.1 & $\begin{array}{l}\text { Melaksanakan } \\
\text { kegiatan FGD }\end{array}$ & Terselenggarannya kegiatan FGD & $\begin{array}{l}\text { Diperolehnya kesepakatan strategi } \\
\text { penumbuhan PWMP }\end{array}$ \\
\hline 2.2 & $\begin{array}{l}\text { Melaksanakan } \\
\text { pelatihan Sekolah } \\
\text { Lapang Agribisnis } \\
\end{array}$ & $\begin{array}{l}\text { Terselenggaranya kegiatan } \\
\text { Sekolah Lapang Agribisnis }\end{array}$ & $\begin{array}{l}\text { Peningkatan kemampauan } \\
\text { berwirausaha bagi peserta PWMP }\end{array}$ \\
\hline 2.3 & $\begin{array}{l}\text { Melaksanakan } \\
\text { Pendampingan Net- } \\
\text { Working }\end{array}$ & $\begin{array}{l}\text { Terselenggarannya kegiatan Net- } \\
\text { Working peserta PWMP dengan } \\
\text { lembaga pembiayaan baik } \\
\text { perbankan maupun BUMN }\end{array}$ & $\begin{array}{l}\text { Terjalinnya kerjasama yang saling } \\
\text { menguntungkan antara peserta } \\
\text { PWMP dengan lembaga } \\
\text { pembiayaan }\end{array}$ \\
\hline 2.4 & $\begin{array}{l}\text { Melaksanakan } \\
\text { pengendalian risiko }\end{array}$ & $\begin{array}{l}\text { Terhindarnya kegiatan usaha } \\
\text { peserta PWMP dari kemungkinan } \\
\text { terjadinya dampak negatif dari } \\
\text { perubahan cuaca, serngan hama- } \\
\text { penyakit dan risiko ekonomi }\end{array}$ & $\begin{array}{l}\text { Kegiatan bisnis peserta PWMP } \\
\text { mencapai pertumbuhan yang } \\
\text { memuaskan partisipan PWMP }\end{array}$ \\
\hline
\end{tabular}

\section{Analisis}

Data dan informasi yang diperoleh sebagai hasil monitoring dan evaluasi pelaksanaan kegiatan pengabdian kepada masyarakat dianalisis menggunakan analisis deskriptif visualisasi tabel dan grafik, selanjutnya dinarasikan dengan memperbandingkan parameter antar antar variabel dengan parameter variabel lainnya atau antar parameter suatu kategori dengan parameter kategori lainnya dalam satu variabel. 


\section{HASIL DAN PEMBAHASAN}

\section{Komitmen Wirausahawan Muda Pertanian}

Para alumni yang terhimpun dalam Kelompok PWMP Tahun 2017 telah menunjukkan komitmennya untuk terus mengembangkan jiwa dan semangat kewirausahaan. Jiwa dan semangat kewirausahaan masih ada, terbukti masih aktifnya kegiatan produksi dan pelayanan jasa. Semangat dan jiwa kewirausahaan tersebut telah mampu mengembangkan peluang bisnis bagi para lulusan perguruan tinggi tidak saja di Pulau Lombok, namun juga di daerah lain di antaranya di Makassar Sulawesi Selatan, yaitu mampu menghantarkan para lulusan perguruan tinggi menjadi job-creator di sektor pertanian (agribisnis), dan mendorong Perguruan Tinggi Pertanian sebagai center of agripreneur developmen berbasis inovasi agribisnis

( http://www.pertanian.go.id/home/?show=news\&act=view\&id=1767).

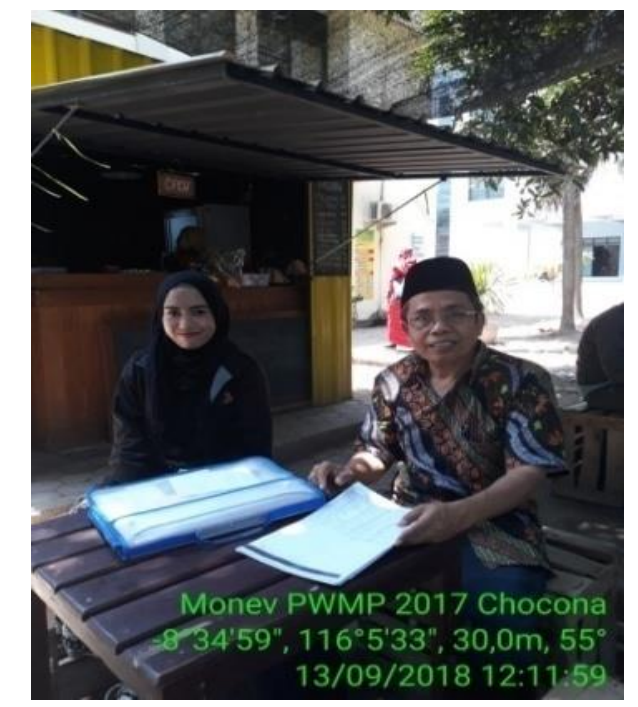

Gambar 1. Kedai Chocona di Kampus Unram di Kota Mataram

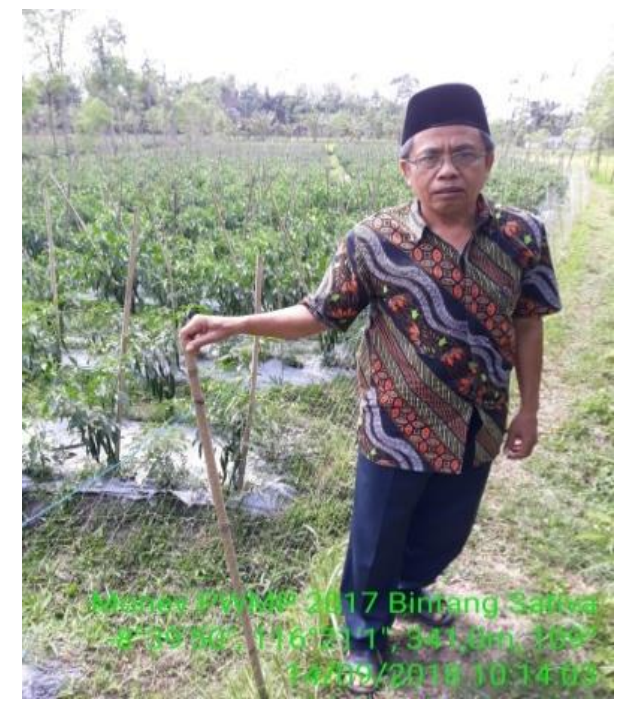

Gambar 2. Lahan Cabe Bintang Sativa di Desa Karang Baru Lombok Tengah

\section{Kapasitas dan Kemampuan Alumni Dalam Pengelolaan Usaha}

Dari 7 (tujuh) Kelompok PWMP Tahun 2017 di antaranya 3 (tiga) kelompok yang telah meningkat kapasitas dan kemampuannya dalam pengelolaan bisnis bidang pertanian. Kapasitas bisnis ditingkatkan dengan cara membuka cabang usaha baru. Peningkatan kemampuan pengelolaan telah ditunjukkan oleh Kelompok Kedai Chocona dan Kedai Coffee Lombok dengan mengangkat karyawan, sehingga mereka dapat mendelegasikan sebagian pelayanan kepada karyawan. Ini mengindikasikan bahwa para alumni Perguruan Tinggi tidak saja sebagai pencari kerja, namun telah mampu sebagai pencipta lapangan kerja bagi orang lain. Hal senada juga diungkapkan oleh Gunawan Yulianto (2016) dalam kunjungan monitoringnya di Yogyakarta bahwa para mahasiswa dan alumni Perguruan Tinggi, bila di bina dan diarahkan akan mampu sebagai job-creator setidak-tidaknya untuk diri mereka sendiri dan juga untuk orang lain.

\section{Kemampuan Pembiayaan Usaha Bidang Pertanian}


Sumber pembiayaan masih dominan bersumber dari modal start-up dari Kementerian Pertanian, kecuali Kelompok PWMP Bintang Tani dan Kelompok PWMP Bintang Sativa yang telah mampu memupuk modal sendiri dari keuntungan usaha yang diperolehnya. Hal ini disebabkan, karena kegiatan usaha masih dalam tahap penyadaran. Dalam tahap penyadaran ini, sumber modal utama adalah berasal dari stimulan yang ditrasfer dari Kementerian Pertanian yang besarnya sebagaimana ditunjukkan pada Tabel 1 berikut.

Tabel 1. Perkembangan Modal Usaha Kelompok PWMP di Pulau Lombok

\begin{tabular}{llccc}
\hline No & Nama Kelompok & $\begin{array}{c}\text { Modal } \\
\text { Start-Up }(\mathbf{R p})\end{array}$ & $\begin{array}{c}\text { Perkembangan } \\
\text { Modal }(\mathbf{R p})\end{array}$ & $\begin{array}{c}\text { Peningkatan } \\
(\boldsymbol{\%})\end{array}$ \\
\hline 1 & Kedai Coffee Juice & $25.000 .000,-$ & $29.000 .000,-$ & 16,0 \\
2 & Bintang Tani & $25.000 .000,-$ & $42.000 .000,-$ & 68,0 \\
3 & Putri Jamer & $25.000 .000,-$ & $27.000 .000,-$ & 8,0 \\
4 & Bintang Sativa & $25.000 .000,-$ & $34.250 .000,-$ & 37,0 \\
5 & Klinik Tani Mandiri & $25.000 .000,-$ & $18.000 .000,-$ & $(28)$ \\
6 & Bukit Aren & $25.000 .000,-$ & $29.800 .000,-$ & 19,2 \\
7 & Kedai Chocona & $25.000 .000,-$ & $27.000 .000,-$ & 8,0 \\
\hline & Jumlah & $175.000 .000,-$ & $207.050 .000,-$ & 18,3 \\
\hline
\end{tabular}

Kemampuan pembinaan bidang usaha agribisnis para alumni menunjukkan peningkatan sebesar 18,3\% dari bulan November 2017 sampai dengan bulan Juli 2018 atau terjadi peningkatan sebesar 2,29\%/bulan lebih besar bila dibandingkan dengan bunga kredit sebesar 0,5\%/bulan.

Berdasarkan perkembangan modal yang ditunjukkan pada Tabel 1 bahwa kegiatan usaha yang dilaksanakan oleh para alumni yang terdiri atas budidaya jamur, budiaya ayam arab, budidaya cabe dan pemasaran produk makanan (coffee) layak untuk dilanjutkan (Pardian dan Firman, 2018), sebab perkembangan usahanya cukup tinggi, sehingga berpeluang untuk mengembangkan usahanya dengan mengusahakan tambahan pembiayaan yang bersumber dari lembaga keuangan perbankan, di antaranya adalah tambahan modal yang bersumber dari skim Kredit Usaha Rakyat (KUR) dan atau dari lembaga keuangan non bank seperti pembiayaan dari Corporate Social Resppnsibility (Tajidan, et al. 2018).

Perkembangan usaha yang dicapai di atas 0,5\%/bulan menunjukkan adanya potensi kemampuan kepemipinnan dan organisasi para alumni yang tergolong baik berdasarkan kriteria kemampuannya dalam menggerakkan para anggota dalam menjalankan kegiatan usaha ekonomi produktif (Mual dan Sritiasni, 2018) di samping kemampuannya dalam mengantisipasi risiko berusaha di antaranya risiko harga, risiko biaya, dan risiko perubahan lingkungan strategis. Hal ini sesuai dengan pendapat dari Husodo dan Suharti (2018) bahwa kemampuan dalam pengendalian risiko menentukan keberlanjutan usaha, serta dapat terhindar dari risiko yang tidak dikehendaki.

\section{Jaringan Agribisnis}

Kegiatan bisnis akan berkembang apabila terbentuk jaringan bisnis (net-working). Jaringan bisnis yang mereka lakukan selama ini masih bersifat bebas (free) tanpa ikatan (contract), hal ini disebabkan usaha yang dilaksanakan masih dalam tahap penumbuhan menuju pengembangan, belum ada kontinyuitas produksi dan pelayanan, karena belum menerapkan bisnis dengan sistem seri, kecuali Kelompok PWMP Bintang Tani yang telah memiliki pelanggan tetap (jaringan pemasaran) bagi 
produk mereka, namun juga belum terikat oleh suatu perjanjian kecuali atas dasar kepercayaan masing-masing pihak satu dengan lainnya.

Dalam rangka pengembangan usaha yang perlu mendapatkan perhatian adalah masalah jaringan bisnis (net working) dalam rangka menuju tahap kemandirian. Membangun jejaring bisnis merupakan tantangan bagi para pemula dalam berwirausaha karena masih dalam tahap pembelajaran. Menurut Hanani, Asmara, Fahriyah, Nugroho (2018) bahwa jejaring bisnis merupakan bagian dari manajemen strategi pemasaran di samping manajemen strategi bauran yang meliputi product, price, place dan promotion.

\section{KESIMPULAN DAN REKOMENDASI}

\section{Kesimpulan}

Alumni Fakultas Pertanian Universitas Mataram yang tergabung dalam Kelompok Penumbuhan Wirausahawan Muda Pertanian (PWMP) telah menunjukkan komitmen sebagai wirausahawan yang diperlihatkan masih bertahannya kegiatan usaha masing-masing. Para alumni yang tergabung dalam Kelompok PWMP memiliki kemampuan dalam meningkatkan kapasitas pengelolaan usaha bidang pertanian diantaranya 3 (tiga) dari 7 (tujuh) Kelompok PWMP telah membuka cabang usaha dan mengangkat karyawan dalam membantu kegiatan produksi dan pelayanan kepada pelanggan.Secara umum telah terjadi peningkatan kemampuan pembiayaan yang bersumber dari penyisihan hasil usaha rata-rata sebesar 18,3\% sejak bulan November 2017 sampai dengan bulan Juli 2018 atau 2,29\%/bulan;Pengembangan jaringan bisnis dan pemasaran masih menjadi kendala bagi sebagian besar wirausahawan muda pertanian, kecuali Kelompok PWMP Bintang Tani yang telah memiliki jaringan bisnis dan pelanggan tetap pada aspek pemasaran.

\section{Rekomendasi}

Agar para alumni mampu mandiri dalam berwirausaha sangat diperlukan dukungan pendampingan berkelanjutan dengan menugaskan para dosen sebagai pembimbing pada tahap penumbuhan dan tahap pemandirian. Para pembimbing dapat membantu anggota Kelompok PWMP dalam memperoleh peningkatan kapasitas pengelolaan usaha bidang agribisnis pada aspek permodalan, kerjasama dan pemasaran.

\section{Ucapan Terima Kasih}

Terima kasih disampaikan kepada semua pihak yang telah menfasilitasi sehingga pelaksanaan kegiatan, seminar dan publikasi pengabdian kepada masyarakat ini dapat terlaksana sesuai harapan.

\section{DAFTAR PUSTAKA}

Agussabti dan Dahlia, 2018. Achievement Motivation. Pusat Pendidikan Pertanian. BPPSDMP. Kementerian Pertanian. Jakarta.

Gunawan Yulianto, 2016. Wirausahawan Muda Pertanian. http://bppsdmp.pertanian.go.id/blog/post/wirausaha-muda-pertanian

Hanani, N., R. Asmara, Fahriyah, CP Nugroho, 2018. Manajemen Pemasaran. Pusat Pendidikan Pertanian. BPPSDMP. Kementerian Pertanian. Jakarta. 
Husodo, S. Dan Suharti, 2018. Manajemen Risiko. Modul Penumbuhan Wirausahawan Muda Pertanian (PWMP). Pusat Pendidikan Pertanian. BPPSDMP. Kementerian Pertanian. Jakarta.

Mual dan Sritiasni, 2018. Organisasi dan Kepemimpinan. Pusat Pendidikan Pertanian. BPPSDMP. Kementerian Pertanian. Jakarta.

Musyadar, A. dan Azhar, 2018. Kewirausahaan. Pusat Pendidikan Pertanian. BPPSDMP. Kementerian Pertanian. Jakarta.

Pardian, P. dan A.Firman, 2018. Manajemen Keuangan (Permodalan dan Perkreditan). Pusat Pendidikan Pertanian. BPPSDMP. Kementerian Pertanian. Jakarta.

Prasetyo dan Sutoyo, 2018. Teknik Evaluasi Kinerja. Pusat Pendidikan Pertanian. BPPSDMP. Kementerian Pertanian. Jakarta.

Suaryantini dan Waluyati, 2018. Strategi Bersaing dan Keberhasilan Usaha. Pusat Pendidikan Pertanian. BPPSDMP. Kementerian Pertanian. Jakarta.

Tajidan, Arifuddin Sahidu, Wiresapta Karyadi, dan I Wayan Suadnya, 2018. Studi Dampak KUR terhadap Kinerja Usahatani Jagung di Kabupaten Lombok Utara. Program Pascasarajana Universitas Mataram. Mataram. 